\title{
A Note on Resolution of Tax Disputes Arising from DTTs and Implications for Developing Countries
}

DOI http://dx.doi.org/10.4314/mlr.v13i3.7

\section{Abstract}

Aschalew Ashagre Byness *

Countries sign bilateral double tax treaties (DTTs) to avoid or mitigate double taxation in cross border economic activity. It is hardly possible to ignore the effect of double taxation in the era of globalization. DTTs are signed between two countries to allocate tax jurisdiction between them and to avoid tax disputes between the taxpayer and the country concerned. Nonetheless, tax disputes crop up since such treaties may be open to interpretation at the time of implementation. Hence, DTTs contain tax dispute resolution mechanism. The widely recognized dispute resolution mechanisms are the mutual agreement procedure (MAP) -a kind of negotiation between the two contracting states- and compulsory arbitration. However, the aptness and efficacy of these tax dispute resolution mechanisms have been seriously questioned particularly from the vantage point of developing countries such as Ethiopia. Although Ethiopia has signed several DTTs with a view to attracting FDI, no study has been made which sheds some light on the essence and operation of the MAP in the DTTs. This note aims at exploring the tax dispute resolution mechanisms incorporated in DTTs since such mechanisms have implication for developing countries including Ethiopia.

\section{Key terms}

Globalization · International taxation · Double taxation $\cdot$ Mutual agreement procedure $\cdot$ Compulsory arbitration

\section{Citation:}

Aschalew Ashagre Byness (2019), 'A Note on Resolution of Tax Disputes Arising from DTTs and Implications for Developing Countries', Mizan Law Review, Vol. 13, No. 3, pp. 495-514.

\footnotetext{
- Aschalew Ashagre Byness (Assistant Professor of Law), PhD candidate, Addis Ababa University School of Law; Consultant and Attorney at law.

ORCID https://orcid.org/0000-0002-1970-7554

This note was part of a paper presented at China-Ethiopia/Africa International Seminar on 26 November 2018, University of Gondar.

Email: gakidan.ashagre335@gmail.com or aschalew.ashagre@aau.edu.et.
} 


\section{Introduction}

The era of globalization is accompanied by cross-border economic activities. ${ }^{1}$ These activities have entailed various issues of international double taxation since there are conflicts of jurisdiction of taxation of sovereign states. Countries cannot ignore the problem of international double taxation, and in effect, they have been taking unilateral and bilateral measures which are meant to mitigate or avoid international double taxation. In unilateral measures, countries make use of exemption, deduction or foreign tax crediting as the case may be. The most important bilateral measures in response to the problem of international double taxation are double tax avoidance treaties otherwise called bilateral tax treaties.

Despite the presence of double tax avoidance treaties, international tax disputes have been common. There have been attempts internationally to put in place tax dispute resolution mechanisms because international tax disputes are important manifestations of international taxation. As the international tax dispute resolution system has an impact on developing countries such as Ethiopia, this note discusses international tax dispute resolution mechanisms. The author tries to examine whether there is adequate international tax dispute resolution system and to highlight the implication in developing countries. To this end, this note addresses four basic themes, i.e., the features international taxation, international double taxation and how can it be remedied, resolution of international tax disputes, and the implication of the international tax dispute resolution system to developing countries such as Ethiopia.

Under the first section, few points regarding globalization and taxation are discussed. The second section deals with some basic points on the causes and remedies of international double taxation. Sections 3 and 4 respectively deal with the international tax dispute resolution system - which involves the mutual agreement procedure (MAP) - and arbitration. The fifth section discusses the implication of tax dispute resolution mechanisms for developing countries such as Ethiopia followed by brief concluding remarks.

\footnotetext{
Frequentl used acronyms:

DTTs Bilateral double tax treaties

FDI Foreign Direct Investment

MAP Mutual Agreement Procedure

MTCs Model Tax Conventions

OECD Organisation for Economic Co-operation and Development

${ }^{1}$ See Muhammad Akram Ch., Muhammad Asim Faheem, Muhammad Khyzer Bin Dost and Iqra Abdullah (2011), 'Globalization and its Impacts on the World Economic Development', International Journal of Business and Social Science, Vol. 2 No. 23, Special Issue, December 2011.
} 


\section{Globalization and International Taxation: An Overview}

As noted in various literature, the world has experienced two globalization booms. The first boom began as of 1820 s which lasted until the outbreak of the First World War while the second boom began following the conclusion of the Second World War which has continued to date. ${ }^{2}$ The phenomenon of globalization at the end of the $20^{\text {th }}$ century and at the dawn of the $21^{\text {st }}$ century is the outcome of two important international developments. The first factor is the general removal of exchange controls by developed countries while the second relates to the growth of new technologies particularly computer-based data processing and communications such as the Internet. ${ }^{3}$ These data processing and communication technologies have made global communication virtually instantaneous. These developments have made worldwide swift financial transactions possible resulting in highly mobile financial capital in an unprecedented manner. Global communication has also enabled transnational corporations (TNCs) to make very quick decisions on a global basis. ${ }^{4}$

Needless to say, globalization has produced various economic and noneconomic effects. One of the most important effects of globalization is international taxation which basically pertains to the question as to how to divide the international tax base in the absence of a higher authority since globalization has increased mobility of capital. ${ }^{5}$

According to Mitchell A. Kane, international taxation is composed of both unilateral domestic law and treaty law on the taxation of transactions that fall within the taxing jurisdiction of more than one sovereign state. ${ }^{6}$ International taxation is anchored on two fundamental principles. These principles are the residence principle and the source principle. In the residence principle, "the place of residency of the taxpayer is taken as the basis of assessment of tax

\footnotetext{
${ }^{2}$ See J. G. Williamson (1992), 'Winners and Losers over TWO Centuries of Globalization,' National Bureau of Economic Research Working Paper, No. 9161, available at www2.econ.uu.nl/users/marrewijk/.../williamson\%202002\%20winners\%20losers.pdf, accessed on December 13, 2017.

${ }^{3}$ See generally Roxana Ian (2012), 'Limits to Globalization: Some Implications for Taxation, Tax Policy and the Developing World,' LSE Law, Society and Economy Working Paper Series, 3/2012. Law Department, London School of Economics and Political Science, London, UK, p.4.

${ }^{4}$ Ibid

${ }^{5}$ Eduardo Baistrocchi (2008), The Use and Interpretation of Tax Treaties in the Emerging World: Theory and Implications, Reprinted from British Tax Review Issue 4, Sweet \& Maxwell Limited, 100 Avenue Road, Swiss Cottage, London, NW3 3PF, p. 4.

${ }^{6}$ Mitchell A. Kane (2015), 'A Defense of Source Principle in International Taxation', 32 Yale Journal on Regulation, p. 312.
} 
liabilities". ${ }^{7}$ On the other hand, the source principle gives attention to the source of the income as the basis for assessing tax liability. According to the former principle, residents of a country are required to pay tax uniformly on their worldwide income irrespective of the country where that income is generated. According to the source principle, on the other hand, income derived in the home country is uniformly taxed in disregard of the residency of the recipient of the income. ${ }^{8}$ Countries have adopted the mixture of these two principles of international taxation with a view to maximizing their tax revenues. However, the combined application of these two principles inevitably results in international double taxation. ${ }^{9}$

\section{International Double Taxation: An Overview of Causes and Remedies}

International double taxation refers to the levying of taxes on the same income or capital of the same taxpayer in the same period by two or more jurisdictions. ${ }^{10}$ International double taxation manifests itself in different forms occurring in various situations. Generally, international double taxation is classified into juridical double taxation and economic double taxation. In the case of juridical double taxation, the same income is being taxed twice in the hands of the same taxpayer while economic double taxation refers to the situation where the same income is being taxed twice in the hands of two different taxpayers. ${ }^{11}$ International double taxation is attributable to three basic reasons, i.e., (i) residence-residence conflict, (ii) source-source conflict, and (iii) source-residence conflict.

Residence-residence conflict:

Two states may tax the same person (an individual or a company) on his/her/its worldwide income or capital owing to inconsistent definitions of residence. For example, a company may be considered as resident of state $\mathrm{X}$ because the company was incorporated in state $\mathrm{X}$, while state $\mathrm{Y}$ may consider it as its

\footnotetext{
7 Jacob Frenkel, Assaf Razin and Efraim Sadka, 'Basic Concepts of International Taxation', NBER Working Papers Series, National Bureau of Economic Research, December, 1990, available at www.nber.org/papers/w3540.pdf, accessed on December 15, 2017.pp. 2-3.

${ }^{8}$ Ibid

${ }^{9}$ Ibid

${ }^{10}$ See Paul L. Baker (2012), An analysis of Double Taxation Treaties and their Effect on Foreign Direct Investment, University of Cambridge, p. 2.

${ }^{11}$ See Introduction to International Double taxation and Tax Evasion and Avoidance; Committee of Experts on International Cooperation in Tax Matters, Seventh Session, Geneva 24-28, October 2011, available at www.un.org/esa/ffd/tax/seventhsession/CRP11_Introduction_2011.pdf, accessed on December 15, 2017, p. 12.
} 
resident based on the company's operations and effective management in state Y. As a result, the income of such company is exposed to international double taxation. $^{12}$

Source-source conflict

Such conflict is also a source of international double taxation. This is because two states may claim power to tax the same income owing to conflicts in the way the source of income is determined under their domestic legislation. ${ }^{13}$

Source-residence conflict

A state may claim that it has the power to tax a certain income invoking the residence principle while the other state claims the power to tax using the source principle. For instance, company $\mathrm{A}$ is incorporated in state $\mathrm{X}$ while it is generating its income in state $\mathrm{Y}$. In this case, state $\mathrm{X}$ claims the power to tax on the basis of the residence principle, and state $\mathrm{X}$ claims the power to tax using the source principle. Therefore, company A is exposed to double taxation. ${ }^{14}$

Although international double taxation cannot be avoided from the very outset, there are remedies that can be utilized to mitigate or eliminate international double taxation. The discussion on the remedies would indeed benefit from prior attention to the reasons that dictate countries to address the problem of international double taxation.

International double taxation should be mitigated or avoided as far as possible because it is a serious obstacle for the movement of capital, goods and services. It also affects the cooperation and financial relations between countries. International double taxation affects import and export neutrality of capital, distorts efficient allocation of scarce economic resource internationally, affects the fairness of a given tax system and it is a cause for international tax avoidance, tax evasion and aggressive tax planning; it is also an obstacle to the development of economic relations between states reducing the revenue of international operators and their interests in making investments abroad. ${ }^{15}$

With a view to addressing these adverse effects, methods of mitigating or eliminating international double taxation have been designed and put into practice. The methods are generally classified into two basic categories. These are: unilateral remedies and bilateral remedies. Unilateral remedies are provided by an individual country using its own domestic tax legislation since it is not

\footnotetext{
${ }^{12} \mathrm{Id}, \mathrm{p} .13$.

${ }^{13}$ Ibid.

${ }^{14}$ Ibid.

${ }^{15}$ Nicoleta Barbuta and Florin Tudor, The International Double Taxation: Causes and Avoidance, available at www.academia.edu/.../The_International_Double_Taxation_causes_and_avoidance, accessed on January $5,201 \overline{8}$, p. 1 .
} 
easy to ignore international double taxation. In this regard, there are three major mechanisms put in place by various countries. These are: tax exemption, foreign tax crediting, and deduction for foreign taxes paid.

With regard to the first method, if a country has provided in its domestic tax legislation that it exempts income from a specified economic activity that is not, for example, produced within its territory, international double taxation is eliminated. If the exemption method is accepted, no further mechanism is necessary to eliminate or mitigate double taxation. ${ }^{16}$

The second unilateral method of reducing the burden of international double taxation is the foreign tax credit method. The essential feature of this method is that the resident state treats a foreign income tax paid to the source state by its residents as though it were paid to itself. ${ }^{17}$ The operation of foreign tax crediting, as a method of mitigating double taxation, depends on the tax rates prevailing both in the source country and the country of residence. Hence, where the foreign tax rate is lower than the domestic tax rate, only the excess of the domestic tax over the foreign tax is payable to the residence state. However, no tax is payable to the residence state where the foreign tax rate is equal or higher than the tax rate prevailing in the country of residence. ${ }^{18}$

The third unilateral mechanism of minimizing the burden of international double taxation is the deduction method. Under this method, it is merely the burden of double taxation that is reduced, rather than eliminating double taxation. This is contrary to the exemption and foreign tax crediting methods. ${ }^{19}$

Despite the prevalence of the above mentioned unilateral methods of dealing with international double taxation, bilateral methods through bilateral tax treaties are commonly practised. Bilateral tax treaties aim at effectively breaking down the barriers of international trade by eliminating double taxation and prevention of fiscal evasion. ${ }^{20}$ The majority of the bilateral tax treaties are

${ }^{16}$ See Yoseph Edrey and Adrienne Jeffrey (1991), 'Taxation of International Activity: Over Relief from Double Taxation under the US Tax System', 9 International Taxes and Business Law, Berkeley Journal of International Law, Issue No. 1, pp. 106-107.

${ }^{17}$ See Introduction to International Double Taxation and Tax Evasion and Avoidance, Committee of Experts on International Cooperation in Tax Matters Seventh session Geneva, 24-28 October 2011, available at www.un.org/esa/ffd/tax/seventhsession/CRP11_Introduction_2011.pdf, accessed on 20 December 2017, p.18.

${ }^{18}$ Ibid

${ }^{19}$ Yoseph Edrey and Adrienne Jeffrey cited above at note 17, P.111.

${ }^{20}$ See OECD Model Tax Convention on Income and on Capital and Commentary, Condensed Version, 15 July 2014, available at www.law.uh.edu/faculty/wstreng/InternationalTax2015/OECDModelTreaty-2014.pdf, accessed on December 5, 2017, p.7. 
negotiated based on two international model tax conventions (MTCs). These are the OECD model and the UN model double tax treaties. ${ }^{21}$ Going through the model tax conventions and bilateral tax treaties, we can observe two methods of avoidance of international double taxation, i.e., the exemption method and the foreign tax credit method. ${ }^{22}$

\section{The Mutual Agreement Procedure in Tax Dispute Resolution}

International tax disputes are common despite the presence of domestic tax laws and bilateral tax treaties. Brauner notes that "the grand illusory of a single, worldwide tax system that would eliminate all international inefficiencies and assist all nations of the world in maximizing their relative advantage is commonly accepted as utopia". ${ }^{23}$ Thus the causes of international tax disputes that emanate from bilateral tax treaties and the methods of resolving such disputes have been issues of academic discourse. The discussion in this section covers mutual agreement procedure (MAP). International tax dispute arbitration and the implication of the international dispute resolution system for developing countries are respectively highlighted in Sections 4 and 5.

\subsection{The function, operation and outcomes of the MAP}

The Mutual Agreement Procedure has been an essential element of bilateral treaties. It is based on the OECD and the UN Model Tax Conventions (MTCs). Art. 25(1) of the two Model Tax Conventions is a crucial procedural provision regarding the application and implementation of bilateral treaties. It provides for the establishment of an international tax dispute resolution procedure called a 'Mutual Agreement Procedure' (hereinafter the MAP). This procedure enables the contracting parties to apply the substantive provisions contained in bilateral tax treaties which allocate taxing rights between contracting states. ${ }^{24}$ Art. 25 of both models, entrust the power - to administer the MAP- to the competent authorities that are envisaged under Art. 3(e) of the Model conventions. They are the organs normally responsible for the administration of the tax treaties. ${ }^{25}$

\footnotetext{
${ }^{21}$ See the two models and compare them with bilateral tax treaties.

${ }^{22} \mathrm{Ibid}$

${ }^{23}$ Yariv Brauner (2003), 'An International Tax Regime in Crystallization', 56 Tax Law Review, 259, p.1.

${ }^{24}$ Hugh Ault (2013), 'Dispute Resolution: The Mutual Agreement Procedure,' in Alexander Trepelkov, Harry Tonino and Dominika Halka,(eds.), United Nations Handbook on Selected Issues in Administration of Double Tax Treaties for Developing Countries, United Nations, New York, p.309.

${ }^{25}$ In bilateral tax treaties signed between Ethiopia and various countries, it has been stipulated that the Ethiopian Ministry of Finance and Economic Cooperation is the competent authority.
} 
According to Art. 25(2) of the MTCs, the role of the competent authorities is to "endeavor to resolve" by mutual agreement difficulties or doubts emanating from the application of the treaties. With a view to ensuring the proper functioning of the tax authorities, Art. 25 has given taxpayers the right to request the competent authority to adjust their tax liabilities in accordance with the tax treaty when they (the taxpayers) believe that they are not taxed in accordance with the substantive rules of the treaty.

Cases initiated by taxpayers represent a significant portion of the cases submitted for the MAP. ${ }^{26}$ The cases arise in relation to various issues such as transfer pricing disputes, ${ }^{27}$ allocation of profits under Article $7^{28}$ of the Model Conventions, and the existence of permanent establishment or the appropriate residence of an individual or a company.$^{29}$ In addition to initiation by taxpayers, the competent authorities may also initiate cases to resolve doubts and uncertainties concerning the application of the treaty. They can do this by formulating -an agreed-upon- meaning to a term which is not defined in the treaty with the purpose of ensuring uniform and consistent application. Moreover, the competent authorities are allowed to conduct mutual consultations towards the avoidance of double taxation where it is not regulated in the treaty. ${ }^{30}$

Article 25(4) of the Model Tax Conventions authorizes the competent authorities to communicate in writing or through oral communication. It is meant to avoid cumbersome formal rules usually employed in intergovernmental communications. This informal mode of communication gives the competent authorities the opportunity to make efficient communication through face-to-face meetings, exchange of documents or position papers and other forms of informal contacts. ${ }^{31}$ Art. 25(4) envisages the possibility of developing bilateral procedures by the competent authorities to deal with various detailed questions which are crucial for the implementation of the MAP.

The outcome of the MAP depends on who has initiated it. Where the MAP is initiated by the taxpayer, the normal result is an agreement between the competent authorities regarding the way the treaty is applied in the taxpayer's case. In such cases, both competent authorities apply the same interpretation of

\footnotetext{
${ }^{26}$ Ault, cited above at note 29, p. 310.

${ }^{27}$ To have a clear picture of cases involving transfer pricing disputes and how such disputes are resolved through the MAP, see Yitzhak Hadari (1998), 'Resolution of International Transfer Pricing Disputes', Canadian Revenue Journal, Vol. 46, No.

${ }^{28}$ The provision deals with the allocation of business profits between the contracting parties.

${ }^{29}$ Ault, cited above at note 29, p. 310 .

${ }^{30}$ Ibid

${ }^{31}$ Ibid
} 
the treaty, ${ }^{32}$ and the taxpayer is free to accept or reject the outcome of the MAP. A taxpayer who accepts the outcome of the MAP is compelled to give up domestic remedies in the two jurisdictions. On the contrary, the taxpayer has the right to seek relief from the judiciary or an administrative tribunal where he rejects the outcome of the MAP. The MAP procedure initiated by the competent authority results in the publication of some other sort of advice which indicates how the two states will apply the treaty. ${ }^{33}$

\subsection{The nexus between MAP and domestic remedies}

A close reading of Art. 25 of the Model Tax Conventions indicates that the presence of the MAP cannot oust the normal domestic legal remedies available to a taxpayer. It is thus important to inquire into the exact relation between the two systems of relief. If a taxpayer submits his grievance to a domestic court/administrative tribunal and such court or tribunal renders decision, the competent authority may be bound by the decision and may not be in a position to give a unilateral relief.

Where resort to domestic relief and the MAP are available to the taxpayer, it is imperative to have rules which establish the relation between the two systems. That is why there can be cases where states demand the taxpayer to waive all his rights under domestic law before the acceptance of the case by the competent authorities for MAP. ${ }^{34}$ This is meant to address concerns against ultimate rejection by a taxpayer after resources and efforts are devoted to find a solution through the MAP. However, this approach of the state is not usual. Rather, more commonly, states require the taxpayer to suspend the active pursuit of his domestic law remedies while the MAP case is being implemented. In such circumstances, it is advisable to the taxpayer to take the necessary steps -as required under domestic law- to maintain the domestic law remedies available in case the MAP fails to produce a result which is satisfactory to the taxpayer. ${ }^{35}$

\section{3 MAP initiated by the taxpayer: basic requirements}

A taxpayer can initiate the MAP where he meets the basic requirements. The first basic requirement is residence. According to Art. 25(1) of the two Model Tax Conventions, a taxpayer is allowed to initiate the MAP provided that he/she/it is a resident of one of the contracting parties. Secondly, the taxpayer has to establish that an action by one or both of the contracting states results in or will result in taxation contrary to the tax treaty. ${ }^{36}$ The request is to be made to the state of which the taxpayer is resident although his claim relates to taxation

\footnotetext{
${ }^{32}$ See Art. 25 of both Model Tax Conventions.

${ }^{33}$ Ibid.

${ }^{34}$ Ault, cited above at note 30, p. 310 .

${ }^{35}$ Id., p. 311.

${ }^{36}$ Ibid.
} 
imposed by the other state. A taxpayer has the right to initiate the MAP if the action of one or both of the contracting states has the potential to bring about taxation inconsistent with the treaty. It is to be noted that it is not a requirement that the taxpayer has already been charged tax. ${ }^{37}$

The taxpayer who requests the MAP should provide necessary information to the competent authorities for the MAP to be successful. In this regard, some countries have developed a formal procedure which should be followed by the taxpayer when he makes MAP requests. ${ }^{38}$ If the taxpayer fails to discharge his duty of providing information, it is justified for the competent authority to suspend the MAP request or to reject the request altogether.

The third basic requirement is payment. Article 25 of both Model Conventions do not require the taxpayer to pay the tax before initiating the MAP. However, there are international practices where states require taxpayers to pay the assessed tax liability before the beginning of the MAP. Such requirement has to be considered very seriously because it would not be in line with the basic purposes of the MAP since it requires the advance payment of the disputed tax obligation. Even where the tax paid in advance is ultimately refunded to a taxpayer whose claim prevails, the taxpayer will suffer from the loss of time value of money (TVM) in relation to the payment. ${ }^{39}$

The fourth basic requirement is time limit that should be met by the taxpayer who initiates the MAP. Art 25(1) of both Model Conventions provides that the taxpayer must present the case for MAP relief within three years of the first notification of the action taken by one of the states which has resulted in or will result in taxation not in accordance with the treaty. The purpose of this requirement is to protect the competent authorities from late-filed objections to the application of the treaty rules.

However, it is to be noted that the three years period provided in the Model Tax Conventions is a recommendation. Contracting states are thus free to determine a shorter or longer period. What exactly constitutes 'notification' for the purpose of establishing the period in which the taxpayer can present a claim is very crucial, and it has been clarified in the commentaries to the Model Conventions. According to these commentaries, notification is generally manifested by the act of taxation itself, the payment of an amount which is

\footnotetext{
${ }^{37}$ Ibid.

${ }^{38}$ These authorities generally have developed the procedure having in mind the United Nations Guide to the MAP. In this regard, See United Nations Guide to the Map, paragraph 74, available at www.un.org/esa/ffd/tax/gmap/Guide_MAP.pdf, accessed on January 6, 2018.

${ }^{39}$ Ault, cited above at note 29, p. 316.
} 
subject to a withholding tax or the actual issuance of a tax assessment notice or official demands for collection. ${ }^{40}$

\subsection{Evaluation of the MAP request, unilateral resolution by a state, and bilateral negotiations}

When the taxpayer submits to the competent authority a MAP request by fulfilling the afore-mentioned requirements, the latter is duty-bound to determine if the objection appears to be justified. ${ }^{41}$ Art. $25(2)$ of both Model Tax Conventions seems to have given a wide discretion to the competent authority of the residence country. Scholars argue that the best practice is to be liberal in granting MAP requests. ${ }^{42}$ In some cases, there may be domestic law which is an impediment to accepting the case. Some states refuse to accept the MAP request where they believe that the transaction in question has been found to be abusive. Nonetheless, the commentaries to the Model Tax Conventions indicate that generally there should not be denial to the MAP request. ${ }^{43}$

On the other hand, where there are violations of domestic law which involve significant penalties, some states may decline from accepting the MAP request. As clearly provided under Art. 25 of the two Model Tax Conventions, a residence country to which a MAP request is submitted should first attempt to resolve the case unilaterally. It may do this, for instance, by granting tax credit or giving an exemption. If the country is not in a position to resolve the case unilaterally, its competent authority then contacts the competent authority of the partner state to commence bilateral negotiations. ${ }^{44}$

If unilateral resolution of the case is not possible, the first step in the bilateral MAP is for the residence state to develop a position paper which provides detailed statement of its views on the case. The position paper is expected to contain the name, address and TIN (Tax Identification Number) of the taxpayer, contact information regarding the competent authority's officials in charge of the MAP case, a summary of the issues, the relevant facts and the basis for the tax administration action that is the subject of the MAP request, the taxation

\footnotetext{
${ }^{40}$ See the UN MTC commentary, p.376.

${ }^{41}$ See Art. 25(2) of both Model Tax Conventions.

${ }^{42}$ See Manual on Effective Mutual Agreement Procedures (MEMAP), Centre for Tax Policy and Administration, OECD, 2007version, available at https://www.oecd.org/ctp/38061910.pdf, accessed on January 23, 2018.

${ }^{43}$ See paragraph 26 of the Commentary on Article 25 of the OECD Model Convention and paragraph 9 of the Commentary on Article 25 of the United Nations Model Convention, quoting paragraph 26 of the Commentary on Article 25 of the OECD Model Convention.

${ }^{44}$ Ibid
} 
years or periods involved, the amount of income and the relevant tax for each taxable period involved. ${ }^{45}$

The other state may find it useful to provide rebuttal or response upon the receipt of the initial position paper from the competent authority of the residence state. The response is expected to indicate whether a view, resolution or proposed relief presented in the initial position paper can be accepted, an indication of the areas of issues where the competent authorities are in agreement or disagreement, requests for any required additional information or clarification, other additional information deemed relevant to the case but not presented in the initial position paper and alternative reasoned proposals for resolution. ${ }^{46}$ After this exchange of views, the competent authorities will continue their discussion towards final resolution. If no agreement is reached, the case may be submitted to arbitration if the countries have adopted mandatory arbitration as provided in alternative B of Art. 25 of the UN Model Tax Convention or Art. 25(5) of the OECD Model Tax Convention.

\subsection{Participation of the taxpayer in the MAP process}

Once the taxpayer has made a MAP request, the MAP is a government-togovernment relationship since the taxpayer has no direct standing in the case. ${ }^{47}$ Yet, a successful MAP requires close cooperation between the taxpayer and the competent authorities. This cooperation is useful because the taxpayer provides information to the competent authority in its state of residence. The competent authority of the country of residence can in turn communicate the information to the competent authority of the other state. The need to request further information may be felt by the competent authorities. The taxpayer may also be requested to provide clarification on points which are not clear to the competent authorities. The competent authorities have the power to permit the taxpayer to submit briefs or make presentations to either one or both of them. However, direct participation of the taxpayer in the negotiation of the competent authorities is not appropriate given the differing interests of the parties. ${ }^{48}$

\subsection{Implementation of the MAP Result}

If the MAP negotiations successfully end up in an agreement on the appropriate interpretation and application of the treaty in the case, some steps need to be taken for the implementation of the MAP agreement. To begin with, the MAP outcome has to be accepted by the taxpayer since it is not binding on the

\footnotetext{
${ }^{45}$ See UN Guide to the MAP, cited above at note 42, paragraph 170.

${ }^{46} \mathrm{Id}$, paragraph 173.

${ }^{47}$ See Limor Riza (2014), “Taxpayers' Lack of Standing in International Tax Dispute Resolutions: An Analysis Based on the Hybrid Norms of International Taxation”, Pace Law Review, Volume 34, Issue 3.

${ }^{48}$ The UN Guide to the MAP, cited above at note 42, paragraphs 149-154.
} 
taxpayer. In fact, the legal status of the agreement and the actual steps necessary for its implementation depend on the prevailing normal procedures in the two countries. According to Art. 25(2) of both Model Conventions, a MAP agreement shall be implemented notwithstanding any time limits of domestic law. This obligation may require changes in the domestic limitations rules to provide specific exceptions for adjustments arising under the agreement.

\subsection{Merits and demerits of the MAP: An overview}

Although MAP is not compulsory and binding, it is claimed that it is advantageous both to the governments concerned and the taxpayer. It is argued that the MAP protects state sovereignty because competent authorities have meaningful control over the application of the treaty. The competent authorities have the freedom to interpret the rules to their benefit. Countries rely on MAP as their sole authority. MAP is also appreciable because it provides for a process of finding an agreeable solution to existing dispute. ${ }^{49}$ Since MAP is a process involving negotiation between the competent authorities which "endeavor to resolve the dispute," it is not detrimental to established international relations between jurisdictions. ${ }^{50}$

MAP is applauded because it is not expensive and imposes little or no administrative burden especially when it is compared with various domestic and international litigation procedures. ${ }^{51}$ It is argued that the MAP is advantageous to taxpayers as well. For instance, as the taxpayer is not involved in the MAP process, he/she/it does not incur cost. The other advantage to taxpayers is that because the process is based on negotiation, both competent authorities will implement the decision due to their involvement and full participation in the course of reaching the decision. ${ }^{52}$ Furthermore, the MAP is advantageous to the taxpayer since the additional time provided to the taxpayer, whilst the competent authorities negotiate, gives him a tactical edge to consider any future resource. ${ }^{53}$

The main disadvantage of MAP is that no result may be obtained since the outcome is determined by the free will of the contracting states. The other disadvantages of MAP are the uncertainty it entails, absence of transparency, and lack of legal obligation on the part of competent authorities to provide a solution due to which the problem faced by the taxpayer will remain unresolved

\footnotetext{
${ }^{49}$ Z.M. Altman (2005), Dispute Resolution under Tax Treaties, IBFD Doctoral Series, p. 253

${ }^{50}$ Hugh Ault, Dispute Resolution: the Mutual Agreement Procedure, Papers on Selected Topics in Administration of Tax Treaties for Developing Countries, 2013, available at $<$ www.un.org/esa/ffd/tax/2013TMTTAN/Paper8A_Ault.pdf $>$, accessed on December 28, 2017, p.3.

${ }^{51}$ Altman, cited above at note 49, p. 254.

${ }^{52} \mathrm{Id}$, p. 266.

${ }^{53}$ Ibid
} 
even after the initiation of MAP. Because MAP may not result in the resolution of the dispute, costs incurred by the competent authorities in the course of conducting the negotiation, and the time and energy can fail to bring about useful outcomes. ${ }^{54}$ The other disadvantage of MAP is that the aggrieved taxpayer is totally excluded from the MAP putting him at the mercy of the competent authorities although their decision ultimately affects the taxpayer. ${ }^{55}$

\section{Arbitration of International Tax Disputes}

The OECD committee on fiscal affairs made an extensive review of the possible use of arbitration to settle international tax disputes in 1984. However, it concluded that compulsory arbitration was not recommendable because it believed that compulsory arbitration would contravene state sovereignty. ${ }^{56}$ In 1995, the OECD reopened the investigation into a more structured approach for the resolution of international tax disputes. The purpose was to critically analyse whether the introduction of a tax arbitration process would be an appropriate addition to the international tax dispute resolution system. ${ }^{57}$ The OECD found it necessary to supplement the MAP as it was considered as an inefficient international tax dispute resolution. ${ }^{58}$ Accordingly, the OECD added paragraph $5^{59}$ to Art. 25 which introduced the practice of mandatory arbitration. ${ }^{60}$ It allows

${ }^{54}$ Id, p. 259.

${ }^{55}$ See Limor Riza, cited above at note 51.

${ }^{56}$ Ehab Farah (2009), 'Mandatory Arbitration of International Tax Disputes: A Solution in Search of a Problem', Florida Tax Review, Vol.9, No.8, p.7.

${ }^{57}$ Altman, cited above at note 49, p. 65.

${ }^{58}$ Ibid

59 This paragraph reads: where:

(a) under paragraph 1, a person has presented a case to the competent authority of a Contracting State on the basis that the actions of one or both of the Contracting States have resulted for that person in taxation not in accordance with the provisions of this Convention, and $(b)$ the competent authorities are unable to reach an agreement to resolve that case pursuant to paragraph 2 within two years from the presentation of the case to the competent authority of the other Contracting State, any unresolved issues arising from the case shall be submitted to arbitration if either competent authority so requests. The person who has presented the case shall be notified of the request. These unresolved issues shall not, however, be submitted to arbitration if a decision on these issues has already been rendered by a court or administrative tribunal of either State. The arbitration decision shall be binding on both States and shall be implemented notwithstanding any time limits in the domestic laws of these States unless both competent authorities agree on a different solution within six months after the decision has been communicated to them or unless a person directly affected by the case does not accept the mutual agreement that implements the arbitration decision. The competent authorities of the Contracting States shall by mutual agreement settle the mode of application of this paragraph.

${ }^{60}$ The UN Model Tax Convention has also provided the same paragraph under alternative B of Art.25. 
the taxpayer to initiate an arbitration process if the MAP fails after two years from the date of its commencement. It is to be noted that the taxpayer is allowed to invoke arbitration only when the competent authority has initiated a MAP and the tax dispute has not been resolved by the negotiation of the competent authorities.

If an agreement is reached by the tax authorities that is not to the satisfaction of the taxpayer, the latter does not have the right to take his case to arbitration. In other words, the arbitration process can only be invoked by the taxpayer for deadlocks and for cases which have been initially justified by the competent authority. Consequently, arbitration is not applicable if the competent authority refuses to initiate the MAP from the very beginning. ${ }^{61}$ Even though Art. 25 of the OECD embraces mandatory arbitration, precise arbitration procedure is not provided in the model. Rather the model has left it to mutual decision by the contracting parties. Therefore, there are individuals who believe that it is inefficient to set up rules on ad hoc basis.

Mandatory arbitration of international tax disputes has been supported by some global organizations and NGOs such as the London Court of International Arbitration (LCIA) and the International Chamber of Commerce (ICC). For instance, in 2000, the ICC Commission on Taxation published a policy statement on arbitration in tax matters, which could easily be adopted in bilateral tax treaties. ${ }^{62}$ As compared to the existing MAP and judicial procedures, the following three arguments are forwarded in support of arbitration:

Process finalization argument: It is obvious that arbitration is similar to a judicial preceding and differs from the MAP since arbitration results in an award which is as good as a court decision. Because of this attribute, arbitration is said to be better than the MAP. ${ }^{63}$

Neutrality argument: international tax dispute arbitration is better than the MAP because its outcome is based on an independent forum instead of interested and biased tax authorities which are expected to give priority to the interests of their state. ${ }^{64}$ Since arbitrators are expected to be independent, they can overcome the biased advantage given to the host state which is involved in the dispute in different capacities: party, regulator, legislator and adjudicator". ${ }^{65}$

\footnotetext{
${ }^{61}$ See Farah, cited above at note 60, pp.716, 734-736.

${ }^{62}$ See Limor Riza, cited above at note 51, p.1072.

${ }^{63}$ Gustaf Lindencrona (1994), 'Recent Development of Tax Treaty Arbitration', in Resolution of Tax Treaty Conflicts by Arbitration 3, 8, p.8.

${ }^{64}$ See generally Barry Bracewell-Milnes (1994), 'Summary of Proceedings of the Seminar', in Resolution of Tax Treaty, Conflicts by Arbitration 61, 62.

${ }^{65}$ This quotation was mentioned with regard to investment treaty arbitration. See, Susan D. Franck (2005), 'The Nature and Enforcement of Investor Rights under Investment
} 
Where the tax dispute involves large-scale trading and financial activities conducted by multinational enterprises, each state would work to enhance its own interest at the expense of the other state ${ }^{66}$ in contrast to the noninvolvement of the contracting states in the dispute-resolution process under arbitration thereby rendering it more politically and procedurally neutral. ${ }^{67}$

Efficiency argument: as compared to the ordinary judicial proceeding, one apparent advantage of arbitration is that it saves cost and time because it is free from the strict procedural and evidentiary rules. It is also argued that arbitral decision is final since the parties cannot lodge appeal against the arbitral award, in effect, making arbitration significantly cost effective. ${ }^{68}$

The arguments raised against arbitration are: the fairness and confidentiality argument, and the sovereignty argument. The fairness and confidentiality argument notes that secrecy is the Achilles heel of the arbitration mechanism, and lack of transparency is the main drawback of arbitration as compared to judicial proceedings. International tax arbitration has been totally obscure from the public ${ }^{69}$ since arbitration process and its final decision are not open. This is said to be a fertile ground for corruption when the parties cannot rely the process. ${ }^{70}$

According to the proponents of the sovereignty argument, arbitration impairs sovereignty of states since internal tax revenue decisions are left to the resolution of third party arbitrators. ${ }^{71}$ Because the resolution of international tax disputes requires the interpretation of domestic laws, some scholars argue that the task of interpretation should be left to domestic courts or tribunals. ${ }^{72}$

\footnotetext{
Treaties: Do Investment Treaties Have a Bright Future', 12 University of California,

Davis Journal of International Law and Policy, 47, 71-72.

${ }^{66}$ Limor Riza, cited above at note 51, p.11.

${ }^{67}$ Park, cited above, at 36.

${ }^{68}$ Ibid

${ }^{69}$ Limor Riza, cited above at note 51, p. 12 .

${ }^{70} \mathrm{Ibid}$

${ }^{71}$ Farah cited above at note $60, \mathrm{p} 709$.

${ }^{72}$ Limor Riza, cited above at note 51, p.13.
} 


\section{The Implication of the Tax Dispute System (Related to DTTs) for Developing Countries}

Developing countries have been taking various measures which are thought to be instruments towards attracting FDI. ${ }^{73}$ This includes the bilateral double tax treaties (DTTs) signed by developing countries with capital exporting countries with the purpose of avoiding international double taxation since double taxation is a hindrance to the flow of FDI to such countries. ${ }^{74}$

Developing countries enter into DTTs with capital exporting countries using either the OECD or the UN Model Tax Convention. In effect, they have adhered to the international tax dispute resolution system embodied in Art. 25 of the two Model convntions. As discussed in Section 3 (above), the MAP is not compulsory. Many developing countries have not been using the MAP as an international dispute resolution mechanism although it has been expressly included in bilateral tax treaties they have so far signed. ${ }^{75}$ Since the negotiation exercise in MAP is not an easy task, it is advisable for developing countries to enhance their negotiating capacity and their competence in the application and interpretation of DTTs.

The use of compulsory arbitration as an international tax dispute resolution mechanism has also been seriously questioned on the basis of the UN Model or the OECD Model. The two models have some clear differences as far as arbitration of international tax disputes is concerned. A close scrutiny of the two models reveals that there are four differences between these model tax conventions:

a) The UN model provides that unresolved MAP cases shall be referred to arbitration after three years from the commencement of the MAP while the OECD model provides that arbitration is to be initiated after two years. ${ }^{76}$ This difference is attributable to the intention in the UN model to give a

\footnotetext{
${ }^{73}$ See Kangning Xu and Paulo Elicha Tembe (2012), 'Attracting Foreign Direct Investment in Developing Countries: Determinants and Policies: A Comparative Study between Mozambique and China', International Journal of Financial Research, Vol. 3, No. 4; 2012.

${ }^{74}$ See Julia Braun and Martin Zagler (2014), ‘An Economic Perspective on Double Tax Treaties with(in) Developing Countries', World Tax Journal, October 2014

${ }^{75}$ See Mutual Agreement Procedure -Dispute Avoidance and Resolution, Committee of Experts on International Cooperation in Tax Matters, the United Nations, Fourteenth Session Geneva, 17-20 October 2017, available at www.un.org/esa/ffd/wp.../2017/.../15STM_CRP26_Mutual-Agreement-Procedure.pdf, accessed on December 25, 2017.

${ }^{76}$ Compare Art. 25 of the UN MTC, which has not contained arbitration with alternative B of Art. 25 (5) of the the same document.
} 
longer period of time to initiate arbitration owing to resource and capacity limitations of developing countries. ${ }^{77}$

b) According to the UN Model, arbitration is to be initiated by one of the competent authorities rather than by the taxpayer contrary, and this varies from what is as provided under the OECD model. ${ }^{78}$

c) The UN Model allows competent authorities to depart from the arbitral award within six months after the award is handed down where they can jointly agree on a different solution. However, under the OECD model, an arbitral award is binding, and the competent authorities are bound to implement the award. ${ }^{79}$

d) Contrary to Art. 25 of the OECD Model, the arbitration clause is only included in one of the two alternatives in Art. 25(B) of the UN Model. This demonstrates that the UN model's approach is more cautious since such approach is beneficial to developing countries. This is because Art. 25(A) does not include an arbitration clause. ${ }^{80}$

A fundamental concern thus arises regarding the implication of the differences between Art. 25 of the two models as far as arbitration is concerned. The differences in the arbitration provisions of the two models have significant implications on the special needs and concerns of developing countries. The express retention of the MAP under Art. 25(A) of the UN Model without arbitration is a clear reflection of the general reluctance of developing countries to compulsory and binding arbitration of international tax deputes. The reluctance of developing countries to arbitration is attributable to limited experience and unfamiliarity with arbitration of tax disputes.

The other reasons are doubts regarding the neutrality of arbitrators and public policy issues related to third party adjudication of such issues. Moreover, the potential cost of arbitration and its possible asymmetrical impact on developing countries are other reasons that have made these countries reluctant to arbitration of international tax disputes. Most importantly, international tax dispute arbitration would affect sovereignty of states. ${ }^{81}$ Countries are generally sovereign in their tax affairs. Yet, tax sovereignty cannot be absolute in the era

\footnotetext{
${ }^{77}$ See generally Dispute Settlement: Arbitration Issues for Developing Countries and Possible Ways Forward, a report produced by Committee of Experts on International Cooperation in Tax Matters, Tenth Session Geneva, the UN, 19-23 October 2015, available at www.un.org/esa/ffd/wpcontent/.../2015/10/11STM_CRP8_DisputeResolution.pdf, accessed on Jan. 2, 2017, p.10.

${ }^{78}$ Compare the two articles of the two MTCs.

${ }^{79}$ See the material cited above at note 80, p. 10 .

${ }^{80}$ Ibid.

${ }^{81}$ Ibid.
} 
of globalization because the tax sovereignty of a country can be constrained by the policies of other countries. ${ }^{82}$

In light of the value attached to tax sovereignty, the legal regimes of developing countries in general embody constitutional and legal clauses that place taxation in the impenetrable realm of sovereignty. Examples in this regard include countries where fiscal sovereignty is embedded in the concept of public order, sovereign economic policy or the catchall notion of public policy. For instance, tax disputes are not submitted to arbitration in Colombia since doing so would go against public order. As Kollmann et al observed, ${ }^{83}$ in Colombia, public order refers to precepts that cannot be ignored by particular agreement as long as they are pertinent to the state's public, economic and social interests. Likewise, Ecuador's Arbitration Law embodies a clause which makes it clear that sovereignty issues like taxation are excluded from the domain of arbitration. Arbitration of tax disputes is not also acceptable in Argentina. ${ }^{84}$

Ethiopia has been exerting efforts to attract foreign direct investment as an instrument for growth and development. The measures taken by Ethiopia towards attracting FDI include signing bilateral investment treaties (BITs) and double tax avoidance treaties. ${ }^{85}$ Because these treaties naturally incorporate principles of international taxation -including the source principle and the residence principle - international double taxation is inevitable. ${ }^{86}$ Therefore, Ethiopia has taken unilateral measures such as foreign tax crediting and tax exemption. ${ }^{87}$ In addition to the unilateral measures, Ethiopia has signed several bilateral double tax avoidance treaties with various countries.

Close scrutiny of these bilateral tax treaties reveals that Ethiopia has signed these bilateral tax treaties in accordance with OECD Model Tax Treaty. ${ }^{88} \mathrm{As}$ regards international tax dispute resolution, the bilateral tax treaties signed by Ethiopia and other countries have incorporated the MAP as it is provided under Art. 25 of the OECD Model Tax Convention. This means that Ethiopia has not accepted mandatory arbitration as a means to the resolution of international tax

\footnotetext{
${ }^{82} \mathrm{Id}, \mathrm{p} .19$.

${ }^{83}$ Jasmin Kollmann, Petra Koch, Alicja Majdanska, and Laura Turcan (2013), 'Arbitration in International Tax Matters', Tax Notes International, Vol.77, No.13, March 2013, p.534.

${ }^{84} \mathrm{Id}, \mathrm{p} .537$.

${ }^{85}$ See Martha Belete Hailu and Tilahun Esmael Kassahun (2014), 'Rethinking Ethiopia's Bilateral Investment Treaties in light of Recent Developments in International Investment Arbitration', Mizan Law Review, Vol. 8, No.1, September 2014.

${ }^{86}$ See the Ethiopian Federal Income Tax Proclamation of Ethiopia, Proclamation No 979/2008, Fed. Neg. Gaz., year 22, No.104, Art.7.

${ }^{87}$ Id, Art.45.

${ }^{88}$ In the course of conducting this research work, I have consulted several tax treaties signed between Ethiopia and other countries and have realized that the treaties are influenced by the OECD MTC.
} 
disputes. Ethiopia's approach towards mandatory international tax dispute resolution is the same as the stance taken by developing countries in general since there is a fear that mandatory tax arbitration would seriously impair state sovereignty with regard to taxation. The domestic tax laws of Ethiopia are also cautious because arbitration of tax disputes is not recognized since it is believed that it would affect tax sovereignty. ${ }^{89}$

\section{Concluding Remarks}

In the era of globalization, issues associated with international taxation are multifaceted and complex. Issues relating to the resolution of international tax disputes are among the most important themes that have attracted the attention of international multinational corporations, international organizations, such as the OECD and the UN, and individual sovereign countries. To this end, both the OECD and the UN have put in place an international dispute resolution mechanism called the Mutual Agreement Procedure (MAP). In fact, this procedure has been used in international tax disputes by various countries.

However, the MAP has several defects and disadvantages. Thus, there is the need for the improvement of the international tax dispute resolution system commensurate with the gaps and complexities in international taxation. To this end, both the OECD and the UN have recommended the inclusion of mandatory tax dispute arbitration in their Model bilateral tax treaties. However, the aptness of the compulsory arbitration has been seriously questioned in spite of some strong arguments raised in its favour. Particularly, developing countries are very much hesitant about the relevance of arbitration for the resolution of international tax disputes arising from DTTs since they believe that it would seriously undermine their tax sovereignty.

As demonstrated in the preceding sections of this note, there is no effective and meaningful international tax dispute resolution system that caters for the balanced interests and needs of international community. In this regard, special interests of developing countries should be taken into account because international tax dispute resolution system has significant impact on developing countries. To this end, developing countries are expected to enhance their benefits from the international tax dispute resolution system by balancing their need to attract foreign capital and their inherent tax sovereignty.

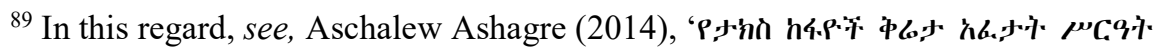

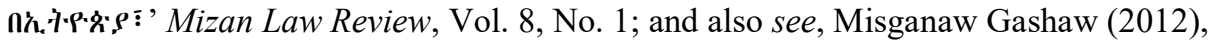
'The Room for Alternative Dispute Resolution (ADR) Process in Tax Disputes: A Message to the Ethiopian Tax Administrations,' in Yazachew Belew (ed.), The Resolution of Commercial/Business Disputes in Ethiopia: Towards Alternatives to Adjudication? Ethiopian Business Law Series, Vol. 5.
} 